\title{
REPRODUCTIVE TRACT INFECTION IN WOMEN ATTENDING OBSTETRICS AND GYNAECOLOGY DEPARTMENT OF A TERTIARY CARE HOSPITAL IN BIHAR
}

\author{
Kahkashan Akhter ${ }^{1}$, Priyadarshini' ${ }^{2}$, Aninda Sen ${ }^{3}$, Sangeeta Dey4, Dharmendra Singh ${ }^{5}$ \\ ${ }^{1}$ Assistant Professor, Department of Microbiology, Katihar Medical College, Katihar, Bihar. \\ ${ }^{2}$ Postgraduate Student, Department of Obstetrics and Gynaecology, Katihar Medical College, Katihar, Bihar. \\ 3 Professor, Department of Microbiology, Katihar Medical College, Katihar, Bihar. \\ 4 Professor, Department of Microbiology, Katihar Medical College, Katihar, Bihar. \\ ${ }^{5}$ Tutor, Department of Microbiology, Katihar Medical College, Katihar, Bihar.
}

\section{BACKGROUND}

\section{ABSTRACT}

Reproductive tract infection (RTI) is a common problem among women and represents a threat to their health. RTI including sexually transmitted disease (STD) and HIV/ AIDS are increasingly being recognised as a serious public health problem. The most common long-term sequelae are pelvic inflammatory disease (PID), cervical cancer, infertility, spontaneous abortion and ectopic pregnancy, which may lead to maternal death. The common infective agents are Gardnerella vaginalis, Trichomonas vaginalis, Candida species and Neisseria gonorrhoeae. Agents such as toxoplasma, rubella, CMV and HSV are important causes of infections during pregnancy. Most of the TORCH infections cause mild maternal morbidity, but have serious foetal consequences.

\section{MATERIALS AND METHODS}

Study Design- This prospective observational study was conducted in the Department of Microbiology, in a tertiary care medical college hospital in eastern Bihar. A total of 200 high vaginal swabs were collected in duplicate from an equal number of patients attending Obstetrics and Gynaecology Department with symptoms suggestive of RTI. In the laboratory one swab was used for culture and identification of the organism, the other was used for direct microscopic examination (Gram stain and wet mount) and other tests like amine test and measurement of $\mathrm{pH}$.

\section{RESULTS}

Maximum patients were seen in the age group of 21 - 30 years, $43.5 \%(87 / 200)$. Least number of cases were seen in the age group of $<20$ years $2.5 \%$ (5/200). Out of the 200 samples processed in the laboratory, 88 were found to show no growth. The most common isolate was Candida species, $25.5 \%$ (51/200). Neisseria gonorrhoeae 0.5\% (1/200) was the least common organism isolated. Moreover, the overall rate of isolation of organisms was higher in patients with bad obstetric history.

\section{CONCLUSION}

Vulvovaginal candidiasis was the most common RTI followed by trichomoniasis and bacterial vaginosis. A single case of gonorrhoea was detected. Interestingly, the incidence of RTI was higher in patients with bad obstetric history.

\section{KEYWORDS}

Reproductive Tract Infection, Pelvic Inflammatory Disease, Bad Obstetric History.

HOW TO CITE THIS ARTICLE: Akhter K, Priyadarshini, Sen A, et al. Reproductive tract infection in women attending Obstetrics and Gynaecology department of a tertiary care hospital in Bihar. J. Evolution Med. Dent. Sci. 2018;7(14):1756-1759, DOI: $10.14260 /$ jemds/2018/396

\section{BACKGROUND}

Reproductive tract infection (RTI) is a common problem among women and represents a threat to their health. Various socio-economic factors are responsible for the development of this disease entity, especially in a country like ours. Infection in the vulva, vagina or cervix represents lower reproductive tract infection and infection in uterus, fallopian tubes and ovaries are considered as upper reproductive tract infection. ${ }^{1}$

\footnotetext{
'Financial or Other Competing Interest': None.

Submission 20-02-2018, Peer Review 18-03-2018,

Acceptance 23-03-2018, Published 02-04-2018.

Corresponding Author:

Dr. Sangeeta Dey,

Professor,

Department of Microbiology,

Katihar Medical College, Karimbagh,

Katihar, Bihar-854105.

E-mail: sangeetadey@rediffmail.com

DOI: $10.14260 /$ jemds $/ 2018 / 396$

RTI including sexually transmitted disease (STD) and RTI including sexually transmitted disease (STD) and HIV/ AIDS are increasingly being recognised as a serious public health problem. The poor health of Indian women is a concern at both national and individual level. Women are not only more susceptible than men to these infections, but also are more prone to develop complications because infection in women is difficult to diagnose and therefore more likely to go untreated. ${ }^{2}$

RTIs often cause discomfort and lost economic productivity. The most common long-term sequelae are pelvic inflammatory disease (PID), cervical cancer, infertility, spontaneous abortion and ectopic pregnancy which may lead to maternal death. The presence of a sexually transmitted infection increases the risk of acquiring and transmitting HIV infection by three to five times and bacterial vaginosis may be a cofactor for HIV transmission, especially among younger women. ${ }^{3}$

The common infective agents are Gardnerella vaginalis, Trichomonas vaginalis, Candida species and Neisseria 
gonorrhoeae. Agents such as Toxoplasma, rubella, CMV and HSV are important causes of infections during pregnancy.

Most of the TORCH infections cause mild maternal morbidity, but have serious foetal consequences. ${ }^{4}$

It is well realised that at least $12 \%-15 \%$ of all recognised conceptions end in miscarriage and pre-clinical pregnancy loss rate is still higher (22\% - 30\%). At present, there is no implicating evidence that bacterial and fungal infections can cause recurrent abortions. ${ }^{5}$ Studies have shown that these infections predispose the patients to acquisition of viral infections like HSV-2 and HIV, which in turn can lead to premature birth and spontaneous abortions. ${ }^{6}$

Reproductive tract infection is the commonest cause of morbidity in the reproductive age group, but the actual magnitude of the problem is grossly underestimated due to serious problems like social stigma. It is therefore imperative that proper initiation must be taken by health care providers to facilitate the diagnosis and treatment of such cases.

The present study was taken up with a view to determining the spectrum of microorganisms responsible for causing reproductive tract infection in our hospital setting and to find a possible correlation between their isolation pattern and obstetric history of the patient.

\section{MATERIALS AND METHODS}

This prospective observational study was carried out in a tertiary care medical college hospital in eastern Bihar. Institutional Ethical Committee clearance was taken before conducting the study. A total of 200 high vaginal swabs were collected in duplicate from an equal number of patients attending Obstetrics and Gynaecology Department with symptoms suggestive of RTI. A brief clinical history regarding occupation, personal hygiene etc. was noted. Obstetric history and history of any antibiotic uptake either topically or systemically was also noted down. Swabs collected were immediately sent to the laboratory for further processing.

In the laboratory one swab was used for culture and identification of the organism, the other was used for direct microscopic examination (Gram stain and wet mount) and other tests like Whiff test (amine test) and measurement of pH. ${ }^{7}$

Gram stained smears were further scored as per scoring system of Nugent et al. A score of $\geq 7$ was indicative of bacterial vaginosis, score of 4 - 6 was taken as intermediate and score of 0 - 3 was considered as normal. ${ }^{8}$

Identification of the organisms isolated was done by study of colony morphology, Gram's staining and motility followed by a battery of biochemical tests.7,9

Neisseria gonorrhoeae was identified by colony morphology on chocolate agar, Gram's stain morphology, catalase, oxidase and rapid carbohydrate utilisation tests. ${ }^{7}$

Gardnerella vaginalis was identified on the basis of presence of $\beta$-haemolytic colonies on human blood Tween 80 bi-layer medium, presence of Gram variable bacilli on Gram staining, starch and raffinose fermentation and hippurate hydrolysis tests. ${ }^{8}$

Candida species was identified by germ tube test, chlamydospore formation on cornmeal agar, sugar fermentation and sugar assimilation test. ${ }^{7}$

Statistical analysis of results was done using the chisquare test. P-value $\leq 0.05$ was considered to be significant and $p$-value $\leq 0.001$ was considered to be highly significant.
All statistical analysis was carried out using online statistical software at-

http://www.physics.csbju.edu/stats/contingency_NROW_NC OLUMN_form.html; accessed on 14.02.2018. All media and reagents were procured from HiMedia Laboratories, Mumbai.

\section{RESULTS}

A total of 200 females were inducted into the study, out of which maximum number of patients were seen in the age group of 21 - 30 years, $43.5 \%(87 / 200)$ followed by age group 31 - 40 years, 39.0\% (78/200). Least number of cases were seen in the age group of $<20$ years $2.5 \%(5 / 200)$ [Table $1]$.

Out of 200 women, $84.5 \%$ (169/200) were multiparous, only $15.5 \% \quad(31 / 200)$ were nulliparous. Among the multiparous women 157 had a good obstetric history (GOH), while 12 had a bad obstetric history (BOH) [Table 2].

On microscopic examination of vaginal swabs 3\% (6/200) patients showed presence of clue cells, 10\% (20/200) showed presence of Trichomonas $s p$. and yeast-like cells were seen in 31\% (62/200) of samples [Table 3].

Overall, RTI was seen in $48.5 \%(97 / 200)$ of patients in the study group, whereas $44.0 \%$ (88/200) showed no growth. The most common isolate was Candida species $25.5 \%(51 / 200)$ followed by non-albicans candida species $5.5 \%(11 / 200)$ and Gardnerella vaginalis 3\% (6/200). Neisseria gonorrhoeae $0.5 \%(1 / 200)$ was the least common organism isolated. Trichomonas vaginalis could be detected by wet mount examination in $10 \%(20 / 200)$ of patients. The overall rate of isolation of organisms was higher in patients with $\mathrm{BOH}$. The differences in rate of isolation of various organisms in patients with $\mathrm{GOH}, \mathrm{BOH}$ and nullipara was found to be highly significant $(p=0.000)$ [Table 4].

As per Nugent criteria, $7 \%(14 / 200)$ of patients were found to have bacterial vaginosis. Out of these 14 patients, both Whiff test and vaginal $\mathrm{pH} \geq 6$ was found to be positive in 85.7\% (12/14) and Gardnerella vaginalis could be grown in only $42.9 \%(6 / 14)$ of cases [Table 5].

\begin{tabular}{|c|c|c|c|}
\hline Age & $\begin{array}{c}\text { No. of Married } \\
\text { Patients (\%) }\end{array}$ & $\begin{array}{c}\text { No. of Unmarried } \\
\text { Patients (\%) }\end{array}$ & Total \\
\hline$\leq 20$ & $2(1.0)$ & $3(100.0)$ & $5(2.5)$ \\
\hline $21-30$ & $87(44.2)$ & 0 & $87(43.5)$ \\
\hline $31-40$ & $78(39.6)$ & 0 & $78(39.0)$ \\
\hline $41-50$ & $30(15.2)$ & 0 & $30(15.0)$ \\
\hline Total & $\mathbf{1 9 7}$ & $\mathbf{3}$ & $\mathbf{2 0 0}$ \\
\hline \multicolumn{4}{|c|}{ Table 1. Age-Wise Distribution of Married } \\
and Unmarried Patients \\
\hline
\end{tabular}

\begin{tabular}{|c|c|c|}
\hline Parity & No. of Patients & Percentage \\
\hline $\begin{array}{c}\text { Multiparous with good } \\
\text { obstetric history }\end{array}$ & 157 & 78.5 \\
\hline $\begin{array}{l}\text { Multiparous with bad } \\
\text { obstetric history }\end{array}$ & 12 & 6.0 \\
\hline Nulliparous & $31^{*}$ & 15.5 \\
\hline Total & 200 & 100.0 \\
\hline \multicolumn{3}{|c|}{ Table 2. Obstetric History of Patients with RTI } \\
\hline
\end{tabular}

*All married and unmarried women who never conceived were included in nullipara. 


\begin{tabular}{|c|c|c|c|c|}
\hline $\begin{array}{c}\text { Diagnostic } \\
\text { Procedure }\end{array}$ & $\begin{array}{c}\text { Clue } \\
\text { Cells (\%) }\end{array}$ & $\begin{array}{c}\text { Trophozoites of } \\
\text { Trichomonas (\%) }\end{array}$ & $\begin{array}{c}\text { Yeast-Like } \\
\text { Organisms (\%) }\end{array}$ & $\begin{array}{c}\text { No. Relevant } \\
\text { Findings (\%) }\end{array}$ \\
\hline Wet-mount $(\mathrm{n}=200)$ & $6(3.0)$ & $20(10.0)$ & $62(31.0)$ & $112(56.0)$ \\
\hline Gram stain $(\mathrm{n}=200)$ & $10(5.0)$ & NA & $62(31.0)$ & $128(64.0)$ \\
\hline \multicolumn{5}{|c|}{ Table 3. Microscopic Findings in Patients with RTI } \\
\hline
\end{tabular}

\begin{tabular}{|c|c|c|c|c|}
\hline Organisms Isolated/Detected & $\begin{array}{c}\text { Multiparous with Good } \\
\text { Obstetric } \\
\text { History (\%)* }\end{array}$ & $\begin{array}{c}\text { Multiparous with } \\
\text { Bad Obstetric } \\
\text { History (\%)* }\end{array}$ & $\begin{array}{c}\text { Nulliparous } \\
\text { (\%) }\end{array}$ & $\begin{array}{c}\text { Total No. } \\
\text { (\%) }\end{array}$ \\
\hline Candida albicans & $44(28.0)$ & $4(33.3)$ & $3(9.7)$ & $51(25.5)$ \\
\hline Non-albicans Candida species & $8(5.1)$ & $2(16.7)$ & $1(3.2)$ & $11(5.5)$ \\
\hline Gardnerella vaginalis" & $5(3.2)$ & $1(8.3)$ & $0(0.0)$ & $6(3.0)$ \\
\hline Trichomonas vaginalis** & $17(10.8)$ & $3(25.0)$ & $0(0.0)$ & $20(10.0)$ \\
\hline Neisseria gonorrhoea & $0(0.0)$ & $1(8.3)$ & $0(0.0)$ & $1(8.3)$ \\
\hline Growth of normal flora & $17(10.8)$ & $1(8.3)$ & $5(16.1)$ & $23(11.5)$ \\
\hline Sterile & $66(42.0)$ & $0(0.0)$ & $22(71.0)$ & $88(44.0)$ \\
\hline Total* $*$ & $\mathbf{1 2}$ & $\mathbf{3 1}$ & $\mathbf{2 0 0}$ \\
\hline \multicolumn{2}{|r|}{} \\
\hline
\end{tabular}

- "lisolated in only 6 of the 14 cases of bacterial vaginosis **detected by microscopy only.

- $\quad{ }^{*}$ p value $=0.000$.

\begin{tabular}{|c|c|c|c|c|c|c|c|c|}
\hline \multirow{2}{*}{$\begin{array}{l}\text { Patients with Bacterial } \\
\text { Vaginosis }(n=14)\end{array}$} & \multirow{2}{*}{ Whiff Test } & \multicolumn{3}{|c|}{ Vaginal pH } & \multicolumn{3}{|c|}{ Nugent Scoring } & \multirow{2}{*}{$\begin{array}{c}\text { Growth of } \\
\text { Gardnerella } \\
\text { Vaginalis }\end{array}$} \\
\hline & & $\mathrm{pH} \leq 4$ & pH 4-6 & $\mathrm{pH} \geq 6$ & $0-3$ & $4-6$ & $\geq 7$ & \\
\hline No. of Positive Cases (\%) & $12(85.7)$ & 00 & $02(14.3)$ & $12(85.7)$ & 00 & 00 & $14(100.0)$ & $06(42.9)$ \\
\hline No. of Negative Cases & $02(14.3)$ & $14(100.0)$ & $12(85.7)$ & $02(14.3)$ & $14(100.0)$ & $14(100.0)$ & 00 & 08 (57.1) \\
\hline \multicolumn{9}{|c|}{ Table 5. Positivity of Various Tests in Patients with Bacterial Vaginosis } \\
\hline
\end{tabular}

\section{DISCUSSION}

Majority of the patients (43.5\%) were in the age group of 2130 years, followed by the age group of $31-40$ years $(39 \%)$. Least number of patients $(2.5 \%)$ belonged to the age group of $\leq 20$ years. This is probably due to the fact that RTIs are more common in the sexually active reproductive age group. Most of the patients, $197 / 200$ were married. Other authors have also reported a higher rate of RTI in married patients as compared to unmarried patients. ${ }^{10}$

Majority of the patients were multiparous $84.5 \%$ $(169 / 200)$, only $15.5 \%(31 / 200)$ were nulliparous which included three unmarried females. Of the multiparous women, 12/200 had BOH. Another author also reported that incidence of RTI increases with parity. RTI was least common in nulliparous (6\%) and highest (76\%) in multiparous women. ${ }^{11}$

Candida species were the most common isolate with an isolation rate of $25.5 \%$ (51/200) for Candida albicans and $5.5 \%(11 / 200)$ for non-albicans candida species. Neisseria gonorrhoeae of $0.5 \%(1 / 200)$ was the least common isolate. $11.5 \%(23 / 200)$ samples showed mixed bacterial growth, while $44 \%$ (88/200) samples were sterile. The high percentage samples showing no growth in culture were probably due to use of self-medication or use of ointments or lotions by the patient. Bacterial vaginosis was seen in $7 \%$ $(14 / 200)$.

Patnaik and Sahu (2008) has reported Candidiasis in $33.9 \%$ of cases, Bacterial vaginosis in $14.3 \%$, Trichomoniasis in $12.5 \%$ and $N$. gonorrhoeae in $1.8 \% .12$ Similarly, Madhivanan and Bartman (2009) have reported the prevalence of $T$. vaginalis as $8.5 \%$ as compared to $10 \%$ in our present study. ${ }^{13}$ In another study the incidence of bacterial vaginosis was reported as $20 \%$, Candidiasis as $12.5 \%, N$. gonorrhoeae as $1.2 \%$ and T. vaginalis as $4.1 \%$. These findings are quite different from those of the present study. ${ }^{14}$

The rate of isolation of various organisms from patients with $\mathrm{BOH}$ was higher as compared to those with $\mathrm{GOH}$. Candida albicans was seen in $33.33 \%$ of patients with $\mathrm{BOH}$ as compared to $28.03 \%$ in GOH, non-albicans Candida species in $16.67 \%$ of patients with $\mathrm{BOH}$ versus $5.09 \%$ in $\mathrm{GOH}$. Gardnerella vaginalis $8.33 \%$ in $\mathrm{BOH}$ versus $3.18 \%$ in $\mathrm{GOH}$. Trichomonas vaginalis was seen in $25 \%$ of patients with $\mathrm{BOH}$ as compared to $10.83 \%$ of patients with $\mathrm{GOH}$.

The differences in isolation rates of organisms in the three groups of patients with RTI viz. multiparous with GOH, multiparous with $\mathrm{BOH}$ and nulliparous was found to be highly significant ( $\mathrm{p}$ value $<0.001$ ). The higher rate of isolation from patients with $\mathrm{BOH}$ is probably due to the fact that although these organisms alone are not very important causes of PID, their presence predisposes carriers to acquire other STIs such as HIV and HSV2 virus that have been implicated in causation of endometritis (PID), resultant $\mathrm{BOH}$ and infertility.

\section{CONCLUSION}

The institution where this study was conducted is located in a small town in eastern Bihar and mainly caters to the rural population of the adjoining areas. This area is part of the Kosi belt, a region known for its poor developmental activities. Consequently, the general population residing here, especially the females are illiterate with poor personal hygiene and occurrence of RTI is a common ailment. In the present study, RTI was seen in $48.5 \%$ (97/200) of patients. Vulvovaginal candidiasis was the most common RTI, followed by trichomoniasis and bacterial vaginosis. A single case of gonorrhoea was detected.

Studies have shown that common bacterial and fungal agents responsible for RTI do not directly lead to premature 
births or recurrent abortions, but their presence predisposes the patients to acquisition of sexually transmitted infections like HSV-2 and HIV, both of which can lead to complications during pregnancy. In our study, the incidence of RTI was higher in the patients with $\mathrm{BOH}$ which corroborates the above theory.

Hence, efforts should be made for early diagnosis and treatment of RTIs, as it not only leads to morbidity and distress in patients but it may result in complications during pregnancy, PID and sometimes infertility.

Awareness and sensitisation towards the problem, so that women take proper and complete course of medications rather than reverting to traditional methods of disease control is the need of the hour. New methodologies and interventions should be set up both at service provider level as well as beneficiary end to bring down prevalence rates of RTI.

\section{REFERENCES}

[1] Gaash B, Kausar R, Bhan R, et al. Reproductive tract infection in Kargil: a community based study. Indian Journal of Practicing Doctors 2004;1(2):342-4.

[2] Srivastava A, Nandan D, Mehrotra AK, et al. A comparative study of perception about reproductive tract infections among married women in rural, urban and urban slum areas. Indian Journal of Community Medicine 2004;29(2):274-8.

[3] Prasad JH, Abraham S, Kurz KM, et al. Reproductive tract infections among young married women in Tamil Nadu, India. International Family Planning Perspectives 2005;31(2):73-82.

[4] Aljumaili ZKM, Alsamarai AM. Risk factors for bad obstetric history in Kirkuk women, Iraq. Int J Infect Microbiol 2013;2(3):70-7.

[5] Devi R, Srinivas N, Rajangam S. Bad obstetric history and infectious causes. Int J Hum Genet 2002;2(4):26971.
[6] Agwu AL, Jang SS, Korthuis PT, et al. Pregnancy Incidence and outcomes in vertically and behaviourally HIV-infected youth. JAMA: The Journal of American Medical Association 2011;305(5):468-70.

[7] Winn W, Allen S, Janada W, et al. In: Koneman's Color Atlas and Textbook of diagnostic microbiology. $6^{\text {th }}$ edn. Philadelphia: Lippincott Williams \& Wilkins 2006:8791, 576-95, 1216-20.

[8] Howard AJ, Catherine AI. Haemophilus, Gardnerella and other bacilli. In: Collee JG, Fraser AG, Marmion BP, et al. eds. Mackie and McCartney Practical medical microbiology. 14th edn. New Delhi: Churchill Livingstone 2008: p. 456-8.

[9] Collee JG, Miles RS, Watt B. Tests for Identification of Bacteria. In: Collee JG, Fraser AG, Marmion BP, et al. eds. Mackie and McCartney Practical medical microbiology. 14th edn. New Delhi: Churchill Livingstone 2008: p. 131-49.

[10] Ram R, Bhattacharya K, Goswami DN, et al. Syndromic approach for determination of reproductive tract infections among adolescent girls. Journal of the Indian Medical Association 2006;104(4):178, 180-1.

[11] Rathore M, Vyas L, Bhardwaj AK. Prevalence of reproductive tract infections among women and sociocultural factors associated with it. Journal of the Indian Medical Association 2007;105(2):71-2, 74, 78.

[12] Patnaik L, Sahu T, Sahani NC. Syndromic diagnosis of RTI/STI among women of reproductive age group. Indian Journal of Community Medicine 2008;4(1):24854 .

[13] Madhivanan P, Bartman MT, Pasutti L, et al. Prevalence of Trichomonas vaginalis infection among young reproductive age women in India: implications for treatment and prevention. Sex health 2009;6(4): 339-44.

[14] Oliviera FA, Pfleger V, Lang K, et al. Sexually transmitted infections, bacterial vaginosis and candidiasis in women of reproductive age in rural Northeast Brazil: a population- based study. Mem Inst Oswaldo Cruz 2007;102(6):751-6. 